\title{
Paediatric tuberculosis diagnosis using Mycobacterium tuberculosis real-time polymerase chain reaction assay: a systematic review and meta-analysis
}

\author{
Emmanuel Oladipo Babafemi ${ }^{*} \mathbb{D}$, Benny P. Cherian, Beatrice Ouma and Gilbert Mangua Mogoko
}

\begin{abstract}
Background: Rapid and accurate diagnosis of paediatric tuberculosis (TB) is key to manage the disease and to control and prevent its transmission. Collection of quality sputum samples without invasion methods from paediatrics (age $<16$ years) with presumptive pulmonary tuberculosis (PTB) remains a challenge. Thus, the aim of this metaanalysis was to assess the overall accuracy of a real-time polymerase chain reaction (RT-PCR)-based assay, for routine diagnosis of MTB in different samples from paediatrics with active pulmonary and extra-pulmonary tuberculosis using mycobacterial culture as the gold standard in clinical microbiology laboratories.
\end{abstract}

Methods: We conducted a systematic review and meta-analysis to examine the diagnostic test accuracy of RT-PCR based assay for the detection of MTB in paediatric clinical samples.

A systematic literature search was performed for publications in any language. MEDLINE via PubMed, EMBASE, and Web of Science were among 9 bibliographic databases searched from August 2019 until November 2020. Bivariate random-effects model of meta-analysis were performed to generate pooled summary estimates ( $95 \% \mathrm{Cls}$ ) for overall accuracy of RT-PCR based assay compared to mycobacterial culture as the reference standard.

Results: Of the 1592 candidate studies, twenty-one eligible studies met our inclusion criteria. In total, the review and meta-analysis included 5536 (3209 PTB and 2327 EPTB). Summary estimates for pulmonary TB (11 studies) were as follows: sensitivity 56 (95\% Cl 51-62), specificity 97 (95\% Cl 96-98) and summary estimates for extra-pulmonary TB (10 studies) were as follows: sensitivity 87 (95\% Cl 82-91)) specificity 100 (95\% Cl 99-100). There was significant heterogeneity in sensitivity and specificity among the enrolled studies $(p<0.001)$.

Conclusions: Our results suggested that the RT-PCR based assay could be a useful test for the diagnosis of paediatrics TB with high sensitivity and specificity in low-income/high-burden and upper medium income/low-burden settings. From the study, RT-PCR assay demonstrated a high degree of sensitivity for extra-pulmonary TB and good sensitivity for pulmonary TB which is an important factor in achieving effective global control and for patient management in terms of initiating early and appropriate anti-tubercular therapy.

Systematic review registration: PROSPERO CRD42018104052

Keywords: Paediatric Tuberculosis, Mycobacterium tuberculosis, Real-time polymerase chain reaction-based assay, Pulmonary samples, Extra-pulmonary samples, Systematic review, Meta-analysis

*Correspondence: boladiipo95@yahoo.com; e.o.babafemi@ljmu.ac.uk

Liverpool John Moores University-City Campus, Liverpool, Merseyside, UK original author(s) and the source, provide a link to the Creative Commons licence, and indicate if changes were made. The images or other third party material in this article are included in the article's Creative Commons licence, unless indicated otherwise in a credit line to the material. If material is not included in the article's Creative Commons licence and your intended use is not permitted by statutory regulation or exceeds the permitted use, you will need to obtain permission directly from the copyright holder. To view a copy of this licence, visit http://creativecommons.org/licenses/by/4.0/. The Creative Commons Public Domain Dedication waiver (http://creativeco mmons.org/publicdomain/zero/1.0/) applies to the data made available in this article, unless otherwise stated in a credit line to the data. 


\section{Background}

Paediatric tuberculosis (PaeTB) diagnosis presents a major challenge [1]. Tuberculosis (TB), an infectious disease caused by the bacillus Mycobacterium tuberculosis (MTB), is spread from person to person predominantly through an airborne route and remains a major global health problem as it causes ill-health among millions of people [2]. TB is the leading cause of death from a single infectious agent (ranking above HIV/AIDS) and about a quarter of the world's population is infected with MTB [3]. According to the World Health Organization, globally, an estimated 10.0 million (range, 8.9-11.0 million) people fell ill with TB in 2019, a number that has been declining very slowly in recent years. However, World Health Organization (WHO) estimates that annually, 1.2 million children have TB disease and many more harbour a latent form of infection [3]. The disease typically affects the lungs (pulmonary TB) but can also affect other sites (extra-pulmonary TB).

This review is important because diagnosis of PaeTB disease in children can be challenging as MTB can only be detected in biologic samples from fewer than $50 \%$ of children with TB $[4,5]$. MTB isolation is difficult due to the paucibacillary nature of the disease hence diagnosis often relies on clinical, epidemiological, radiological, and tuberculin skin test. TB in children is often missed or overlooked due to non-specific symptoms and or nonspecific diagnostic tests $[1,6]$. Ninety-four percent of children with TB are treated empirically in TB high-burden countries with non-specific diagnostic tests [7].

The main challenges and issues which this review aimed to address are lack of accurate estimates due to under-recognition, challenges in diagnosis and non-existent of an accurate diagnostic test to confirm TB in children [8]. The lack of a simple and effective diagnostic test that can be utilised in resource-limited settings, where the infection is endemic, has hindered its control [9]. It is rarely bacteriologically confirmed [10]. Young children are at particular risk of developing severe, often fatal, or life-long disabling forms of TB. In 2019, approximately 230,000 children died of TB, among whom 52,000 were living with HIV (http://www.who.int/tb/publications/ global_report/en). PaeTB remains a major cause of morbidity and mortality globally, particularly in developing countries. Most deaths from PaeTB could be prevented with early diagnosis and appropriate treatment [11]. The actual burden of TB in children is likely higher given the challenge in diagnosing childhood TB in many lowincome countries where the diagnosis of paediatric $\mathrm{TB}$ is solely based on clinical evidence and smear microscopy [10]. These are more difficult in paediatric population as they are unable to produce deep cough for adequate sputum [12]. Gastric aspirate as a sample has the drawbacks that it is minimally invasive and requires fasting state [13]. However, stool as a sample for intrathoracic tuberculosis has been explored on the premise that children usually swallow their sputum and it is convenient to obtain, non-invasive compared to sputum or gastric aspirate [14].

Latent tuberculosis infection (LTBI) is defined as a state of persistent immune response to stimulation by MTB antigens with no evidence of clinically manifest active TB [15]. It is estimated that the lifetime risk of an individual with LTBI for progression to active TB disease is $5-10 \%$ over their lifetime [16]. This risk is particularly high among children under the age of 5 years [17]. Tuberculin skin test (TST) or interferon-gamma release assay (IGRA) can be used to test for LTBI, as there is no 'gold standard' test for LTBI [18]. It is only a marker of exposure rather than disease [1]. Establishing an accurate diagnosis of PaeTB in children can be more difficult than adult TB, because of the challenge children have in expectorating good-quality sputum or absence of lung parenchymal disease as in primary complex [19]. In children, culture methods have a greater, yet highly variable, sensitivity which improve diagnosis but takes between 2 and 8 weeks in most cases and the sputum sample lacks representative of lower respiratory tract $[20,21]$. Other diagnostic approaches are based on clinical presentations, imperfect tools such as radiology which is subject to inter-observer variability to detect radiographic abnormalities, contact history, and tuberculin skin test, all of which are of low specificity [22].

Given the difficulty in diagnosing TB disease in paediatrics this systematic review assesses all the available published primary research studies to provide summary estimates to contribute to rapid and accurate diagnosis of PaeTB using RT-PCR based assays which can improve diagnostic accuracy for diagnosing MTB infection in paediatrics with tuberculosis compared to the mycobacterial culture-based assays. RT-PCR assays are nucleic acid amplification tests (NAATs), which was developed in 1983, and are now a common tool for the rapid diagnosis of many infectious diseases, including PaeTB [2326]. The assay has much better accuracy than sputum smear microscopy [27]. Due to advances in technologies over the past decades, the TB diagnostics pipeline has improved tremendously showing promise $[28,29]$. RTPCR assay is commonly used to determine whether DNA or a unique sequence of the MTB is present in a sample and detects amplified DNA as the reaction progresses in real time [30]. Xpert MTB/RIF (Xpert) (Cepheid, USA), an automated cartridge-based RT-PCR assay, is currently recommended by the World Health Organization (WHO) as the initial diagnostic test in presumptive PTB cases for adults and children [31]. 
The outputs of this systematic review will serve as a resource for decision-makers, providing government stakeholders and healthcare practitioners with the tools to make evidence-based decisions for PaeTB diagnosis and control. It summarises current evidence-based clinical practice that can help to develop future guidelines and healthcare policy when choosing the most appropriate tool for rapid and accurate detection of MTB by RTPCR assay in paediatric clinical samples on routine basis.

\section{Methods}

This review was registered and is in accord with the standardised written protocol (systematic review registration with the International Prospective Register of Systematic Reviews (PROSPERO) database PROSPERO CRD42018104052) that followed the PRISMA-P (Preferred Reporting Items for Systematic Reviews and MetaAnalyses Protocols) statement guidelines [32]. Additional file 1 shows the PRISMA checklist. The published protocol can be accessed on https://systematicreviewsjournal. biomedcentral.com/articles/10.1186/s13643-019-1137y. Quality of included studies was assessed by Quality Assessment of Diagnostic Accuracy Studies-2 (QUADAS-2) [33]. Institutional ethical review approval was not needed for this review.

\section{Strategy \\ Electronic searches}

Search terms ("tuberculosis", mycobacterium tuberculosis, extrapulmonary tuberculosis, pulmonary tuberculosis, paediatric tuberculosis), "Real-time polymerase chain reaction", real-time pcr, real-time pcr assay, "rt-pcr", "Nucleic Acid Amplification Test", "NAAT", "culturebased media", culture-based assay, "liquid media", "solid media", "paediatric", "paediatrics", "children") were used to generate a list of primary studies in any language with no restriction on date of publication, and publication status (see Additional file 2 for search terms). There was no restriction regarding the language, date of publication and publication status. Studies that recruited children less than 16 years of age being investigated for MTB infection using RT-PCR assay across lower- and middleincome countries (LMICs), and Upper middle-income countries (UMICs) accompanied by mycobacteriological culture investigation as the reference standard were included to achieve a more reliable estimate of diagnostic accuracy which is important to ensure that the process of identifying studies is as thorough and unbiased as possible.

Two investigators $(\mathrm{EB}, \mathrm{BC})$ independently and systematically carried out the search. Searches using electronic bibliographic databases (MEDLINE via PubMed, EMBASE, LILACS, BIOSIS Citation Index, Web of
Science, SCOPUS, ISI Web of Knowledge, Cochrane Infectious Diseases Group Specialised Register (CIDG SR), Cochrane Registry of Diagnostic Studies, National Institute for Health Research, PROSPERO, Google Scholar Turning Research into Practice (TRIP) took place in August 2019 and was updated in November 2020. The MEDLINE search strategy is outlined in Additional file 2. The MEDLINE search was imported to EMBASE, Cochrane Infectious Diseases Group Specialised Register and other databases to identify additional records [34, 35]. The search strategy for each database was validated by a librarian information specialist familiar with the topic.

Attempts were made to avoid missing relevant studies by searching other sources such as reference lists of relevant reviews, selected studies, portal of the WHO International Clinical Trials Registry Platform (www.who.int/ trialsearch) to identify ongoing trials, as well as StopTB Partnership's New Diagnostics Working Group (www. stoptb.org/wg/new_diagnostics/), the World Health Organization and Centers for Disease Control and Prevention websites, and proceedings of the International Union Against Tuberculosis and Lung disease (UNION) conference. A search of grey literature including conference proceedings (Conference Proceedings Citation Index-Science (CPCI-S)), Dissertations and Theses (www.proquest.com), and expert information was sought and added to our resource material.

Besides full articles, abstracts, and letters to the editor with sample sizes $>20$ was also considered for inclusion. There was no language limitation to the search. Abstracts or articles in languages other than English were screened using 'Google Translator'.

\section{Inclusion and exclusion criteria}

Study designs such as observational, cross-sectional studies, cohort studies (prospective and retrospective) and case-control designs for the detection of MTB from paediatrics clinical samples of age $<16$ years were eligible for inclusion if the studies (1) compared RT-PCR based assay to a reference/gold standard method- MTB culturebased (either liquid or solid) assay, (2) described original research, (3) reported total number of patients tested and positive/negative results that allowed calculation of true positives (TP), true negatives (TN), false positives (FP) and false negatives (FN). Studies were excluded if (1) RT-PCR assay was not used in the study, (2) if age of participants is $>16$ years, (3) all samples were not tested by reference/gold standard test-MTB culture-based (either liquid or solid) assay, (4) reference test was a combination of greater than one diagnostic test, (5) it included animal studies, (6) RT-PCR based assay was used for detecting non-tuberculosis mycobacteria, (7) RT-PCR based assay 
was used for detecting MTB from clinical isolates and not the pathological specimens/samples and (8) possible duplicate publication, when an author published more than one study. The existence of overlapping study populations was ascertained by checking sample recruitment sites and/or periods. The article reporting on the largest number of samples was included in our study.

\section{Selection of studies}

Full-text articles were screened independently (by EB and BC), using a PRISMA flow chart [32] for eligibility for use in the study to minimise bias in selection. Any disagreements were resolved through discussion and where needed, by a third reviewer (BO). Any rejected studies were documented.

\section{Data extraction}

Data extraction were independently carried out by EB and $\mathrm{BC}$ from each selected study using a predetermined list of categories/characteristics: participants/population, country, index test, reference test, disease and target sequence for detection of MTB DNA in PaeTB (Table 1).

\section{Assessment of study quality}

The methodological quality for the included studies was assessed independently ( $\mathrm{EB}$ and $\mathrm{BC}$ ) according to the four domains (patient selection, index test, reference standard, and flow and timing) of the QUADAS-2 tool [33]. The study QUADAS-2 quality criteria are given in Additional file 3.

\section{Data synthesis and meta-analysis}

We computed measures of test accuracy for each of the included studies using standard methods recommended for meta-analysis of diagnostic studies: sensitivity, specificity, positive likelihood ratio (PLR), negative likelihood ratio (NLR), diagnostic odds ratio (DOR) and 95\% confidence intervals (CI) [56]. The 2 $\times 2$ data (TP, FP, TN and FN) were extracted directly from the included studies. Where this information was not available, values were calculated from the data provided in the article. We used a DOR using the DerSimonian-Laird random-effect model to calculate and assess the overall accuracy. This model accounts for both within-study variability (random error) and between-study variability (heterogeneity) along with the area under the summary receiver operating characteristic (SROC) curve using the bivariate model [57, 58]. The bivariate model considers potential threshold effects and the correlation between binary tests (sensitivity and specificity). These measures were pooled using the random-effects model [57, 58]. Each of the included studies used in the meta-analysis contributed a pair of numbers: sensitivity and specificity. Since these measures are correlated, we summarised their joint distribution using a SROC curve. The SROC curve presents a global summary of test performance and shows the trade-off between sensitivity and specificity. A symmetric curve suggests that the variability in accuracy between studies is explained, in part, by differences in thresholds used by the studies. The area under the SROC curve is a global measure of overall performance of the test. An area under the curve value of 1 indicates perfect discriminatory ability of the test, while an area under the curve value of 0.5 means that the test does not have discriminating ability $[57,58]$.

Data were analysed using Meta-DiSC (version 1.4), Reviewing Manager ver. 5.4 (Cochrane Collaboration, Oxford, UK) $[58,59]$. The data were displayed graphically on forest plots and SROC plots. The SROC curve was fitted using the Littenberg-Moses method [60].

We did not evaluate the publication bias because this is not usually recommended in the meta-analysis for diagnostic test accuracy [61]. Generally, a diagnostic accuracy study does not test a hypothesis; therefore, there is no $p$ value for authors and publishers that may influence decisions about publication which are based on the statistical significance of the results $[61,62]$.

\section{Investigations of heterogeneity}

We investigated heterogeneity because of its critical importance (1) to understand the possible factors that influence accuracy estimates and (2) to evaluate the appropriateness of statistical pooling of accuracy estimates using random-effects meta-analysis to generate sensitivity and specificity with $95 \%$ CIs from various studies [62].

The heterogeneities among the included studies were assessed visually using forest plots and SROC curves with 95\% prediction regions and statistically with chi-squared $(\chi 2)$ and using $I$-squared $\left(I^{2}\right)$ statistics with the following interpretation: $I^{2}=0$, no heterogeneity; $0<I^{2}<25$, mild heterogeneity; $25 \leq I^{2}<50$, moderate heterogeneity; $50 \leq$ $I^{2}<75$, strong heterogeneity; $75 \leq I^{2}<90$, considerable heterogeneity and $90 \leq I^{2}$, extreme heterogeneity $[61,63]$.

Source of heterogeneity was investigated using stratified (subgroup) analyses. The following factors were specified a priori as potential sources of heterogeneity: impact of RT-PCR based assays on lower- and middle -income countries (LMICs) versus Upper middle-income countries (UMICs).

\section{Result}

\section{Study characteristics}

Our search identified 1592 potentially relevant citations, of which 58 studies were selected based on 
Table 1 Characteristics of the included studies

\begin{tabular}{|c|c|c|c|c|c|c|c|}
\hline \multirow[t]{2}{*}{$\begin{array}{l}\text { Author year } \\
\text { (n) }\end{array}$} & \multirow[t]{2}{*}{ Country } & \multirow[t]{2}{*}{ Study design } & \multicolumn{2}{|c|}{$\begin{array}{l}\text { Total number of } \\
\text { samples }(N)\end{array}$} & \multirow[t]{2}{*}{$\begin{array}{l}\text { Reference test: } \\
\text { culture }\end{array}$} & \multirow[t]{2}{*}{$\begin{array}{l}\text { Index test: } \\
\text { RT-PCR }\end{array}$} & \multirow[t]{2}{*}{ Target sequence } \\
\hline & & & РTB & EPTB & & & \\
\hline $\begin{array}{l}\text { Bates et al. (2013) } \\
\text { [36] }\end{array}$ & Zambia-(L) & $\begin{array}{l}\text { Prospective- } \\
\text { descriptive }\end{array}$ & 142 & & $\begin{array}{l}\text { Liquid culture } \\
\text { (MGIT) }\end{array}$ & $\begin{array}{l}\text { RT-PCR Xpert MTB/ } \\
\text { RIF }\end{array}$ & rpoB probe \\
\hline $\begin{array}{l}\text { Bates et al. (2013) } \\
\text { [36] }\end{array}$ & Zambia-(L) & $\begin{array}{l}\text { Prospective- } \\
\text { descriptive }\end{array}$ & & 788 & $\begin{array}{l}\text { Liquid culture } \\
\text { (MGIT) }\end{array}$ & $\begin{array}{l}\text { RT-PCR Xpert MTB/ } \\
\text { RIF }\end{array}$ & rpoB probe \\
\hline $\begin{array}{l}\text { Chipinduro et al. } \\
\text { (2017) [37] }\end{array}$ & Zimbabwe-(L) & A cross-sectional & & 222 (stool) & $\sqcup J$ & $\begin{array}{l}\text { RT-PCR Xpert MTB/ } \\
\text { RIF }\end{array}$ & rpoB probe \\
\hline $\begin{array}{l}\text { El Khechine et al. } \\
\text { (2009) } \\
\text { [38] }\end{array}$ & France-(U) & $\begin{array}{l}\text { Diagnostic case- } \\
\text { control }\end{array}$ & - & 134 & $\begin{array}{l}\text { BACTEC } 9000 \mathrm{MB} \\
\sqcup J\end{array}$ & RT-PCR(MX3000) & IS6110 gene \\
\hline $\begin{array}{l}\text { Gous et al. (2015) } \\
\text { [39] }\end{array}$ & South Africa-(U) & Prospective & 345 & - & $\begin{array}{l}\text { Liquid culture } \\
\text { (MGIT) }\end{array}$ & $\begin{array}{l}\text { RT-PCR Xpert MTB/ } \\
\text { RIF }\end{array}$ & rpoB probe \\
\hline $\begin{array}{l}\text { LaCourse et al. } \\
\text { (2014) [40] }\end{array}$ & Malawi-(L) & $\begin{array}{l}\text { Cross-sectional } \\
\text { study }\end{array}$ & 300 & - & Bactec MGIT, BD) & $\begin{array}{l}\text { RT-PCR Xpert MTB/ } \\
\text { RIF }\end{array}$ & rpoB probe \\
\hline $\begin{array}{l}\text { Memon et al. } \\
\text { (2018) [41] }\end{array}$ & India-(L) & $\begin{array}{l}\text { Diagnostic accu- } \\
\text { racy study }\end{array}$ & - & 100 & Bactec MGIT 960 & $\begin{array}{l}\text { RT-PCR Xpert MTB/ } \\
\text { RIF }\end{array}$ & rpoB probe \\
\hline $\begin{array}{l}\text { Mesman et al. } \\
\text { (2019) [42] }\end{array}$ & Peru-(U) & Cohort study & & 259(stool) & $\begin{array}{l}\text { BACTEC } 9000 \mathrm{MB} \\
\sqcup J\end{array}$ & TruTip Mtb DNA & IS6110 real-time PCR \\
\hline $\begin{array}{l}\text { Nhu et al. (2013) } \\
\text { [43] }\end{array}$ & Vietnam-(L) & Prospective & & 96 & $\begin{array}{l}\text { MGIT, Becton } \\
\text { Dickinson) }\end{array}$ & $\begin{array}{l}\text { RT-PCR Xpert MTB/ } \\
\text { RIF }\end{array}$ & rpoB probe \\
\hline $\begin{array}{l}\text { Nicol et al. (2011) } \\
\text { [44] }\end{array}$ & South Africa-(U) & $\begin{array}{l}\text { Prospective- } \\
\text { descriptive }\end{array}$ & 452 & - & Liquid culture & $\begin{array}{l}\text { RT-PCR Xpert MTB/ } \\
\text { RIF }\end{array}$ & rpoB probe \\
\hline $\begin{array}{l}\text { Nicol et al. (2013) } \\
\text { [45] }\end{array}$ & South Africa-(U) & Prospective & - & 115 & Bactec MGIT 960 & $\begin{array}{l}\text { RT-PCR Xpert MTB/ } \\
\text { RIF }\end{array}$ & rpoB probe \\
\hline $\begin{array}{l}\text { Nicol et al. (2018) } \\
{[46]}\end{array}$ & South Africa-(U) & Cohort study & 367 & - & $\begin{array}{l}\text { MGIT, Becton } \\
\text { Dickinson) }\end{array}$ & $\begin{array}{l}\text { RT-PCR Xpert MTB/ } \\
\text { RIF }\end{array}$ & rpoB probe \\
\hline $\begin{array}{l}\text { Oberhelman et al. } \\
\text { (2010) [47] }\end{array}$ & Peru-(U) & $\begin{array}{l}\text { Prospective case- } \\
\text { control study }\end{array}$ & & 218 (stool, GA, etc.) & $\sqcup$ culture & $\begin{array}{l}\text { hemi-nested } \\
\text { IS6110 PCR }\end{array}$ & IS6110 PCR \\
\hline $\begin{array}{l}\text { Qing-Qin Yin et al. } \\
\text { (2014) [48] }\end{array}$ & China-(U) & Prospective & 255 & & $\begin{array}{l}\text { Solid }(L J) \text { and Liq- } \\
\text { uid culture (Bactec } \\
\text { MGIT } 960\end{array}$ & $\begin{array}{l}\text { RT-PCR Xpert MTB/ } \\
\text { RIF }\end{array}$ & rpoB probe \\
\hline $\begin{array}{l}\text { Rachow et al. } \\
\text { (2012) [49] }\end{array}$ & Tanzania-(L) & $\begin{array}{l}\text { Prospective cohort } \\
\text { study }\end{array}$ & 164 & - & $\begin{array}{l}\text { Solid (LJ) and Liq- } \\
\text { uid culture (Bactec } \\
\text { MGIT } 960\end{array}$ & $\begin{array}{l}\text { RT-PCR Xpert MTB/ } \\
\text { RIF }\end{array}$ & rpoB probe \\
\hline $\begin{array}{l}\text { Sekadde et al. } \\
\text { (2013) [50] }\end{array}$ & Uganda-(L) & $\begin{array}{l}\text { Cross-sectional } \\
\text { diagnostic study }\end{array}$ & 235 & - & $\begin{array}{l}\text { Solid }(L J) \text { and Liq- } \\
\text { uid culture (Bactec } \\
\text { MGIT } 960\end{array}$ & $\begin{array}{l}\text { RT-PCR Xpert MTB/ } \\
\text { RIF }\end{array}$ & rpoB probe \\
\hline $\begin{array}{l}\text { Walters et al. (2017) } \\
\text { [51] }\end{array}$ & South Africa-(U) & Prospective & & 379 (stool) & BACTEC $9000 \mathrm{MB}$ & $\begin{array}{l}\text { RT-PCR Xpert MTB/ } \\
\text { RIF }\end{array}$ & rpoB probe \\
\hline $\begin{array}{l}\text { Wang et al. (2013) } \\
\text { [52] }\end{array}$ & China-(U) & Retrospective & 30 & - & Bact/Alert 3D & $\begin{array}{l}\text { LightCycler }{ }^{\circledR} 480 \\
\text { (Roche) }\end{array}$ & \\
\hline $\begin{array}{l}\text { Wolf et al. (2008) } \\
\text { [53] }\end{array}$ & Peru-(U) & $\begin{array}{l}\text { Diagnostic accu- } \\
\text { racy study }\end{array}$ & - & $16(6+)$ (stool) & & $\begin{array}{l}\text { hemi-nested } \\
\text { IS6110 PCR }\end{array}$ & IS6110 PCR \\
\hline Zar et al. (2012) [54] & South Africa-(U) & Prospective & 535 & - & $\begin{array}{l}\text { Liquid culture } \\
\text { (MGIT) }\end{array}$ & $\begin{array}{l}\text { RT-PCR Xpert MTB/ } \\
\text { RIF }\end{array}$ & rpoB probe \\
\hline Zar et al. (2013) [55] & South Africa-(U) & Prospective study & 384 & - & Bactec MGIT 960 & $\begin{array}{l}\text { RT-PCR Xpert MTB/ } \\
\text { RIF }\end{array}$ & rpoB probe \\
\hline
\end{tabular}

Key: L Löwenstein-Jensen, Middlebrook 7 H9 broth liquid growth medium, Middlebrook $7 H 11$ Solid medium, MGIT mycobacterium growth indicator tube, PTB pulmonary TB, EPTB extra-pulmonary $\mathrm{TB}, n$ reference list number, $L$ lower- and middle-income countries, $U$ upper middle-income countries

relevance to the study topic. An additional 13 studies were identified from grey literature and references of full-text articles. After screening all the titles and abstracts, removing the duplicates and excluding the ineligible studies, 20 articles (5536 samples/patients)
[36-55] were selected for full-text review and metaanalysis (Fig. 1).

Eleven [36, 39, 40, 44, 46, 48-50, 52, 54, 55] reported detection of pulmonary TB (PTB), 10 [36-38, 41-43, $45,47,51,53]$ reported detection of extra-pulmonary 


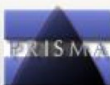

PRISMA 2009 Flow Diagram
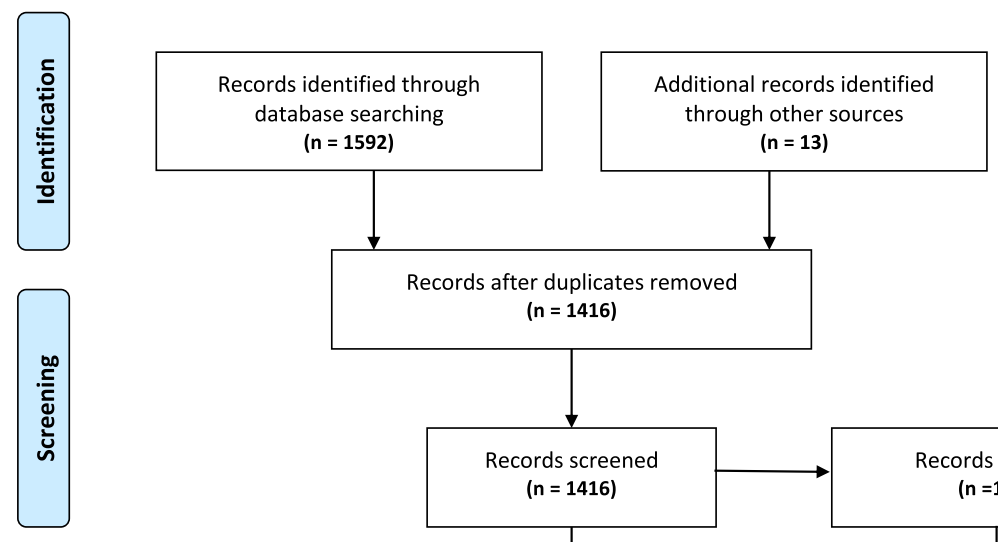

Records after duplicates removed ( $n=1416)$
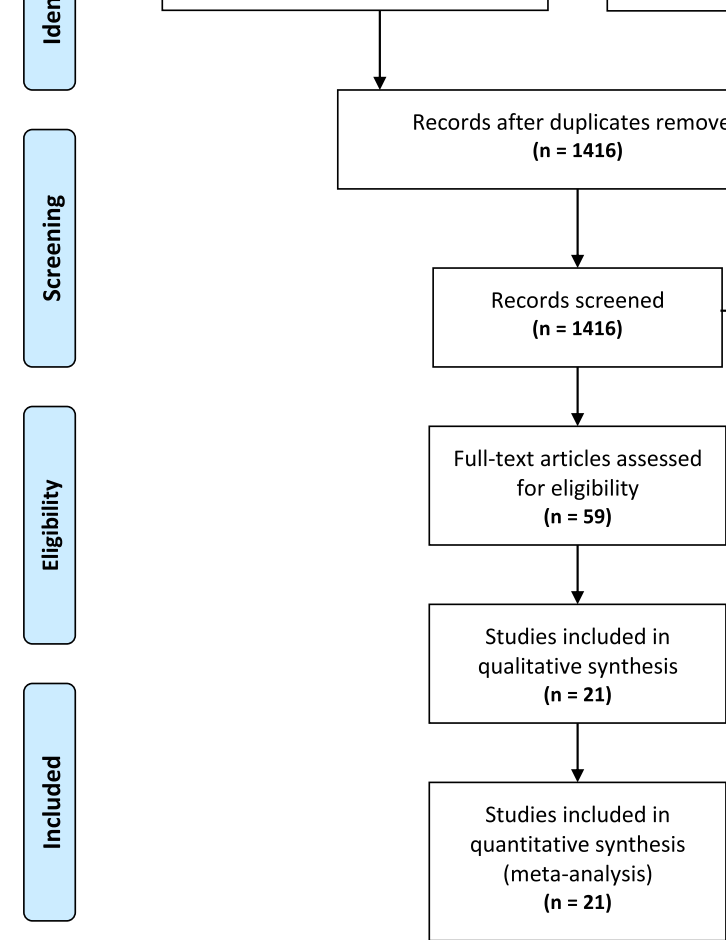

Fig. 1 The Preferred Reporting Items for Systematic Reviews and Meta-Analyses (PRISMA)

TB (EPTB) and 1 [36] reported on both types of clinical sample. Table 1 summarises the main characteristics of the included studies. In total, the review and metaanalysis included 5536 (3209 РTB and 2327 EPTB) clinical samples obtained from 12 countries with high, moderate and low prevalence of PaedTB. There were 12 studies from the developed and eight studies from the developing countries. The studies included in the analysis were conducted in 11 different countries. Most studies ( 8 out of $20,40 \%$ ) were carried out prospectively $[36,39,43-45,48,49,51]$.

Studies included paediatric patients with infections identified in primary, secondary and tertiary healthcare settings (see Table 1). Sixteen studies performed RTPCR based assay using Xpert MTB/RIF on both paediatrics pulmonary and extra-pulmonary clinical samples [36, 37, 39-41, 43-46, 48-52, 54, 55] while 4 studies used other types of RT-PCR based assays to detect MTB from paediatrics extra-pulmonary (stool and gastric aspirates samples [36, 41, 47,60]. Details of the RT-PCR based assays used are summarised in Table 1. The overall study quality assessed by the QUADAS-2 tool showed a low risk of bias except for studies using a case-control design (see Figs. 2 and 3).

The methodological quality of studies (assessed by the QUADAS-2 tool) was generally high, with 37 of the studies meeting all four domains of the criteria (see Figs. 2 and 3). All studies used assays that are based on RT-PCR principle as index test and culture-based assay as the reference test.

\section{Meta-analysis}

Results as 95\% CI values were as follows: overall sensitivity 56 (95\% CI 51-62) and 87 (95\% CI 82-91); 97 (95\% CI 96-98) and 100 (95\% CI 99-100) the values and confidence intervals for specificity are for PTB and EPTB samples, respectively. AUC was 0.98 and 0.99 for PTB and EPTB samples, respectively. 


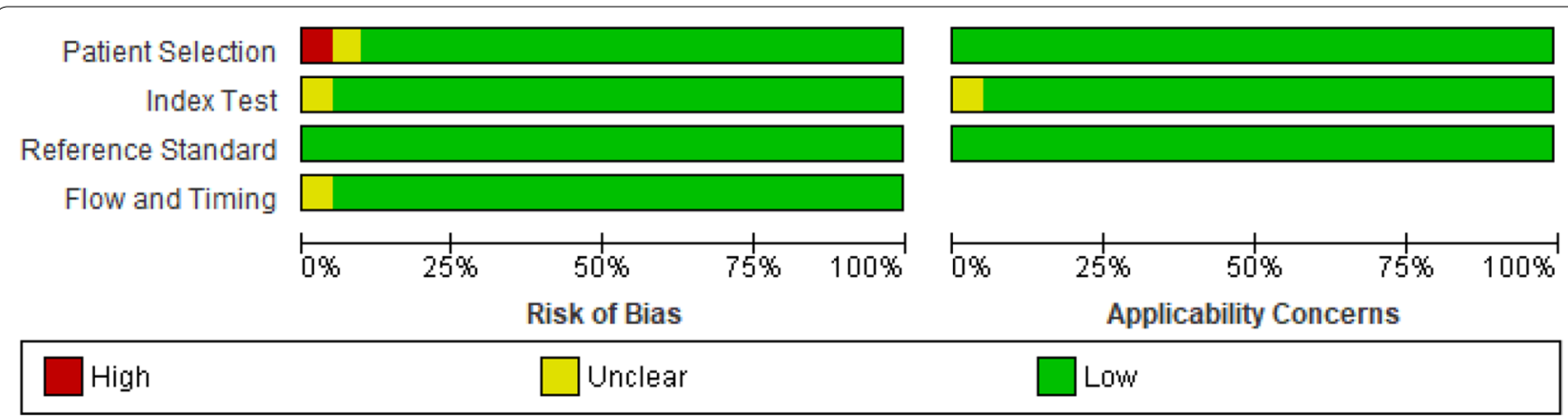

Fig. 2 Risk of bias and applicability concerns graph: review authors'judgements about each domain presented as percentages across included studies

The summary estimates of PTB for heterogeneity with chi-squared $(\chi 2)$ using 95\% CI for sensitivity, specificity, PLR, NLR and DOR were 151.22, 277.67, 205.09, 99.77 and 36.66 respectively, and $p=0$ indicating significant heterogeneity across studies. $I^{2}$ was between 72.7 and $93.4 \%$ showing significant heterogeneity. The summary estimates of EPTB heterogeneity with chisquared $(\chi 2)$ using 95\% CI for sensitivity, specificity, PLR, NLR and DOR were 47.45, 19.19, 11.74, 29.44, and 13.02 respectively, and $p<0.5$ indicating significant heterogeneity across studies. $I^{2}$ was between 30.90 and $81.00 \%$ showing significant heterogeneity. There were considerable heterogeneities (see Table 2, Figs. 4, 5 and 6) in these data.

\section{Subgroup analyses by impact of RT-PCR based assay on countries}

Subgroup analyses by Impact of RT-PCR based assays on lower- and middle-income countries (LMICs) versus upper middle-income countries (UMICs). We assessed sources of data to these graders.

1. With LMICs (Table 1) as the RT-PCR based assay (8 studies, 2,047 specimens), the results were as follows: sensitivity 65 (95\% CI 58-72), specificity 99 (95\% CI, 99-99) and AUC 0.99. A test with perfect discrimination has a ROC curve that passes through the upper left corner (100\% sensitivity, $100 \%$ specificity). The closer the ROC curve to the upper left corner, the higher the overall accuracy of the test. The summary estimates of performance of RT-PCR based assay in LMICs heterogeneity with chi-squared $(\chi 2)$ using 95\% CI for sensitivity, specificity, PLR, NLR and DOR were 44.28, 10.46, 5.97, 29.54 and 11.25 , respectively, and $p=<0.001-0.5$ indicating significant heterogeneity across studies. $I^{2}$ was between 37.8 and $84.20 \%$ showing significant heterogeneity. The results for subgroup analysis by RT-PCR based assay in LMICs are as presented in Table 3 and Additional file 4 and show considerable heterogeneity.
2. With UMICs (Table 1) as the RT-PCR based assay (12 studies, 3489 specimens), the results were as follows: sensitivity 68 (95\% CI 63-73), specificity 97 (95\% CI 96-98) and AUC 0.99. A test with perfect discrimination has a ROC curve that passes through the upper left corner (100\% sensitivity, $100 \%$ specificity). The closer the ROC curve to the upper left corner, the higher the overall accuracy of the test. The summary estimates of performance of RT-PCR based assay in UMICs heterogeneity with chi-squared $(\chi 2)$ using 95\% CI for sensitivity, specificity, PLR, NLR and DOR were 197.71, 291.40, 247.81, 228.53 and 50.80, respectively, and $p=<0.001$ indicating significant heterogeneity across studies. $I^{2}$ was between 37.8 and $84.20 \%$ showing significant heterogeneity. The results for subgroup analysis by RT-PCR based assay in UMICs are as presented in Table 3 and Additional file 5 and show considerable heterogeneity.

\section{Discussion}

Tuberculosis is a global health threat, and early and accurate diagnosis is crucial for preventing morbidity and mortality. Various methods are employed for the diagnosis of TB such as smear microscopy, culture identification, histopathology, tuberculin skin test (TST), serological assays, interferon-gamma release assays (IGRAs) and nucleic acid amplification (NAA) tests [64, 65]. The main advantages of RT-PCR based assay are shortened turna-round time, quantification of bacterial load and automation of the procedure that reduces hands-on time and decreased risk of cross-contamination $[66,67]$.

This review provides evidence on the paediatric tuberculosis diagnosis using Mycobacterium tuberculosis RT-PCR based assay for the rapid and accurate detection of MTB from clinical samples. To our knowledge, this is the first systematic review and meta-analysis for ascertaining the advantage of RT-PCR based assays for the detection of paediatrics MTB from both pulmonary and extra-pulmonary clinical samples. This systematic review and meta-analysis 


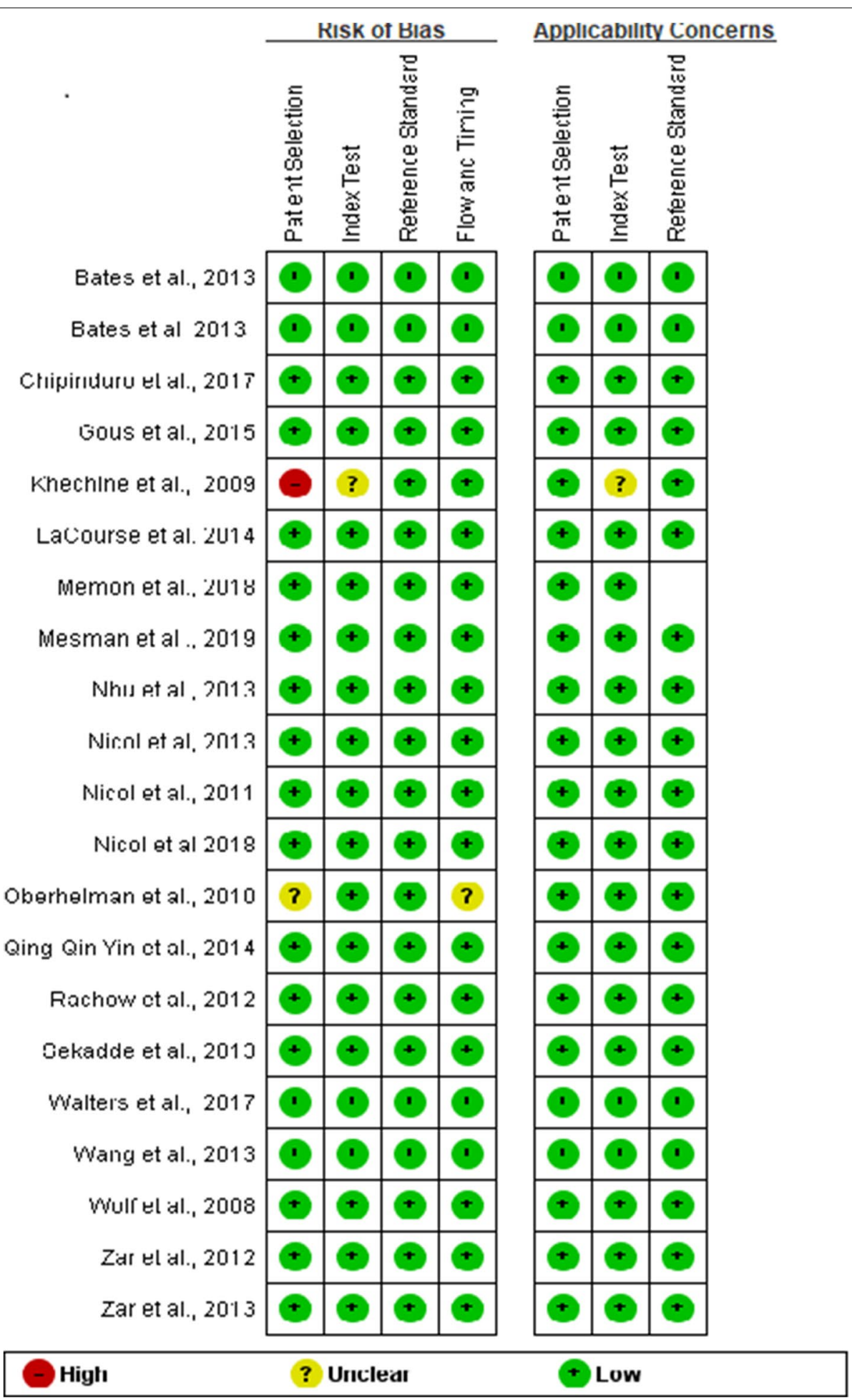

Fig. 3 Risk of bias and applicability concerns summary: review authors'judgements about each domain for each included study

are broader in scope and included other types of RT-PCR based assay other than Xpert MTB/RIF than a previous meta-analysis on this topic [68] and the inclusion of data from low-, middle- and high-income countries.
In this study, results indicated that RT-PCR based assay produces consistent results with high specificity of 97 (95\% CI 96-98), PLR of 70.73 (8.55-585.40) and NLR of $0.43(0.28-0.66)$ for PTB, whereas specificity, PLR and 
Table 2 Summary of statistical results for pulmonary tuberculosis (PTB) and extra-pulmonary tuberculosis (EPTB) clinical samples

\begin{tabular}{|c|c|c|c|c|}
\hline \multirow{2}{*}{$\begin{array}{l}\text { Test property } \\
\text { PTB } \\
\left(n=11^{\text {b }} 3209\right) \\
\text { AUC }=0.98\end{array}$} & \multirow[t]{2}{*}{$\begin{array}{l}\text { Summary of measure test accuracy }{ }^{a} \\
(95 \%)\end{array}$} & \multicolumn{3}{|c|}{ Test of heterogeneity } \\
\hline & & 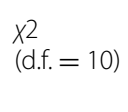 & R & $p$ value \\
\hline Sensitivity & $56(51-62)$ & 151.22 & 93.4 & $<0.001$ \\
\hline Specificity & $97(96-98)$ & 277.67 & 96.4 & $<0.001$ \\
\hline Positive likelihood ratio (PLR) & $70.73(8.55-585.40)$ & 205.09 & 95.1 & $<0.001$ \\
\hline Negative likelihood ratio (PLR) & $0.43(0.28-0.66)$ & 99.77 & 90.0 & $<0.001$ \\
\hline Diagnostic odd ratio (DOR) & $193.06(51.21-727.83)$ & 36.66 & 72.7 & $<0.001$ \\
\hline $\begin{array}{l}\text { EPTB } \\
\left(n=10 ;{ }^{\text {b }} 2327\right) \\
\text { AUC }=0.99\end{array}$ & & $\begin{array}{l}X^{2} \\
(\text { d.f. }=9)\end{array}$ & $1^{2}$ & $p$ value \\
\hline Sensitivity & $87(82-91)$ & 47.45 & 81.00 & $<0.001$ \\
\hline Specificity & 100(99-100) & 19.19 & 53.10 & 0.0236 \\
\hline Positive likelihood ratio (PLR) & $111.91(53.97-232.04)$ & 11.74 & 23.40 & 0.2282 \\
\hline Negative likelihood ratio (PLR) & $0.15(0.07-0.30)$ & 29.44 & 69.40 & 0.0005 \\
\hline Diagnostic odd ratio (DOR) & $1337.84(441.92-4050.12)$ & 13.02 & 30.90 & 0.1610 \\
\hline
\end{tabular}

${ }^{a}$ Random effects model, $x 2$ chi-squared, d.f. degree of freedom, $l^{2}$ l-squared. ${ }^{b}$ number of specimens, $n$ number of studies, $C l$ confidence interval, $A U C$ area under receiver operating characteristics curve, PTB pulmonary tuberculosis, EPTB extra-pulmonary tuberculosis

\begin{tabular}{|c|c|c|c|c|c|c|c|c|}
\hline Study & TP & FP & FN & $\mathrm{TN}$ & Sensitivity $(95 \% \mathrm{Cl})$ & Specificity $(95 \% \mathrm{Cl})$ & Sensitivity $(95 \% \mathrm{Cl})$ & Specificity (95\% Cl) \\
\hline Bates et al., 2013 & 9 & 1 & 2 & 130 & $0.82[0.48,0.98]$ & $0.99[0.96,1.00]$ & - & - \\
\hline Bates et al $2013^{*}$ & 33 & 5 & 15 & 735 & $0.69[0.54,0.81]$ & $0.99[0.98,1.00]$ & & $\square$ \\
\hline Chipinduro et al., 2017 & 13 & 0 & 6 & 199 & $0.68[0.43,0.87]$ & $1.00[0.98,1.00]$ & 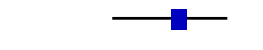 & 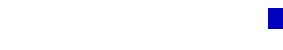 \\
\hline Gous et al., 2015 & 12 & 0 & 0 & 333 & $1.00[0.74,1.00]$ & $1.00[0.99,1.00]$ & & 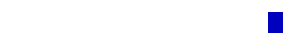 \\
\hline Khechine et al., 2009 & 28 & 3 & 0 & 103 & $1.00[0.88,1.00]$ & $0.97[0.92,0.99]$ & $=$ & \\
\hline LaCourse et al. 2014 & 2 & 0 & 0 & 199 & $1.00[0.16,1.00]$ & $1.00[0.98,1.00]$ & & $\square$ \\
\hline Memon et al., 2018 & 4 & 0 & 2 & 94 & $0.67[0.22,0.96]$ & $1.00[0.96,1.00]$ & & 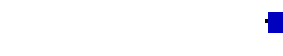 \\
\hline Mesman et al ., 2019 & 18 & 0 & 4 & 241 & $0.82[0.60,0.95]$ & $1.00[0.98,1.00]$ & & $\mathbf{\square}$ \\
\hline Nhu et al., 2013 & 29 & 0 & 0 & 44 & $1.00[0.88,1.00]$ & $1.00[0.92,1.00]$ & $\rightarrow$ & - \\
\hline Nicol et al, 2013 & 9 & 0 & 1 & 105 & $0.90[0.55,1.00]$ & $1.00[0.97,1.00]$ & & 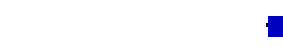 \\
\hline Nicol et al., 2011 & 6 & 0 & 6 & 36 & $0.50[0.21,0.79]$ & $1.00[0.90,1.00]$ & & - \\
\hline Nicol et al 2018 & 64 & 0 & 0 & 303 & $1.00[0.94,1.00]$ & $1.00[0.99,1.00]$ & -1 & $\mathbf{\square}$ \\
\hline Oberhelman et al., 2010 & 21 & 0 & 0 & 128 & $1.00[0.84,1.00]$ & $1.00[0.97,1.00]$ & & 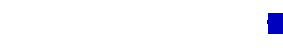 \\
\hline Qing-Qin Yin et al., 2014 & 24 & 62 & 4 & 165 & $0.86[0.67,0.96]$ & $0.73[0.66,0.78]$ & & - \\
\hline Rachow et al., 2012 & 11 & 2 & 17 & 99 & $0.39[0.22,0.59]$ & $0.98[0.93,1.00]$ & 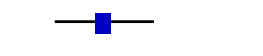 & $t$ \\
\hline Sekadde et al., 2013 & 14 & 0 & 20 & 201 & $0.41[0.25,0.59]$ & $1.00[0.98,1.00]$ & & - \\
\hline Walters et al., 2017 & 24 & 0 & 0 & 327 & $1.00[0.86,1.00]$ & $1.00[0.99,1.00]$ & & $\square$ \\
\hline Wang et al., 2013 & 7 & 0 & 7 & 16 & $0.50[0.23,0.77]$ & $1.00[0.79,1.00]$ & & $\rightarrow$ \\
\hline Wolf et al., 2008 & 6 & 0 & 0 & 16 & $1.00[0.54,1.00]$ & $1.00[0.79,1.00]$ & & $\rightarrow$ \\
\hline Zar et al., 2012 & 23 & 0 & 64 & 387 & $0.26[0.18,0.37]$ & $1.00[0.99,1.00]$ & $\rightarrow$ & च \\
\hline Zar et al., 2013 & 9 & 4 & 21 & 350 & $0.30[0.15,0.49]$ & $0.99[0.97,1.00]_{\digamma}$ & $\sqrt{1}$ & G \\
\hline
\end{tabular}




\begin{tabular}{|c|c|c|c|c|c|c|c|}
\hline Study & TP & FP & FN TN & Sensitivity $(95 \% \mathrm{Cl})$ & Specificity $(95 \% \mathrm{Cl})$ & Sensitivity $(95 \% \mathrm{Cl})$ & Specificity $(95 \% \mathrm{Cl})$ \\
\hline Bates et al., 2013 & 9 & 1 & 2130 & $0.82[0.48,0.98]$ & $0.99[0.96,1.00]$ & & 1 \\
\hline Gous et al., 2015 & 12 & 0 & 0333 & $1.00[0.74,1.00]$ & $1.00[0.99,1.00]$ & & \\
\hline LaCourse et al. 2014 & 2 & 0 & 0199 & $1.00[0.16,1.00]$ & $1.00[0.98,1.00]$ & & \\
\hline Nicol et al., 2011 & 6 & 0 & 616 & $0.50[0.21,0.79]$ & $1.00[0.79,1.00]$ & ta & \\
\hline Nicol et al 2018 & 64 & 0 & 0303 & $1.00[0.94,1.00]$ & $1.00[0.99,1.00]$ & -5 & 口 \\
\hline Qing-Qin Yin et al., 2014 & 24 & 62 & 4165 & $0.86[0.67,0.96]$ & $0.73[0.66,0.78]$ & & $\rightarrow$ \\
\hline Rachow et al., 2012 & 11 & 2 & 1799 & $0.39[0.22,0.59]$ & $0.98[0.93,1.00]$ & -5 & - \\
\hline Sekadde et al., 2013 & 13 & 0 & 20201 & $0.39[0.23,0.58]$ & $1.00[0.98,1.00]$ & $\rightarrow$ & - \\
\hline Wang et al., 2013 & 7 & 0 & 716 & $0.50[0.23,0.77]$ & $1.00[0.79,1.00]$ & $\longrightarrow$ & - \\
\hline Zar et al., 2012 & 23 & 0 & 64387 & $0.26[0.18,0.37]$ & $1.00[0.99,1.00]$ & $\rightarrow$ & - \\
\hline Zar et al., 2013 & 9 & 4 & 21350 & $0.30[0.15,0.49]$ & $0.99[0.97,1.00]_{h}$ & $\sqrt{1}$ & 4 \\
\hline
\end{tabular}

\begin{tabular}{|c|c|c|c|c|c|c|c|c|}
\hline Studv & TP & FP & FN & $\mathrm{TN}$ & Sensitivity (95\% Cl) & Specificity (95\% Cl) & Sensitivity $(95 \% \mathrm{Cl})$ & Specificity $(95 \% \mathrm{Cl})$ \\
\hline Ratec et al $2013^{*}$ & 33 & 5 & 15 & 735 & $0.69[0.54,0.81]$ & $0.99[0.98,1.00]$ & & 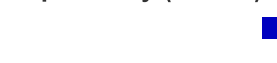 \\
\hline Bates et al LU 13 & 13 & 0 & 6 & 199 & $0.68[0.43,0.87]$ & $1.00[0.98,1.00]$ & & \\
\hline $\begin{array}{l}\text { Chipinduro et al., } 201 / \\
\text { Khechine et al } 2009\end{array}$ & 28 & 3 & 0 & 103 & $1.00[0.88,1.00]$ & $0.97[0.92,0.99]$ & $\rightarrow$ & \\
\hline $\begin{array}{l}\text { Knecrine el al., } \angle 0019 \\
\text { Memon et al. } 2018\end{array}$ & 4 & 0 & 2 & 94 & $0.67[0.22,0.96]$ & $1.00[0.96,1.00]$ & & \\
\hline Mesman et al 2019 & 18 & 0 & & 241 & $0.82[0.60,0.95]$ & $1.00[0.98,1.00]$ & & \\
\hline Nhu et al. 2013 & 29 & 0 & 0 & 44 & $1.00[0.88,1.00]$ & $1.00[0.92,1.00]$ & & \\
\hline Nicet al., ZVIJ 2013 & 9 & 0 & & 105 & $0.90[0.55,1.00]$ & $1.00[0.97,1.00]$ & & \\
\hline Nicol et al, ZUT3 & 21 & 0 & 0 & 128 & $1.00[0.84,1.00]$ & $1.00[0.97,1.00]$ & $\longrightarrow$ & \\
\hline Walters et al., 2017 & 24 & 0 & & 327 & $1.00[0.86,1.00]$ & $1.00[0.99,1.00]$ & & \\
\hline Wolf et al., 2008 & 6 & 0 & 0 & 16 & $1.00[0.54,1.00]$ & $1.00[0.79,1.00]$ & $\begin{array}{llllllll} & 1 & & 1 & 1 \\
0 & 0.2 & 0.4 & 0.6 & 0.8 & 1\end{array}$ & 40.60 .81 \\
\hline
\end{tabular}

NLR were 100 (95\% CI 99-100), 111.91 (53.97-232.04) and $0.15(0.07-0.30)$, respectively, for EPTB. A PLR of 71 suggests that patients with a pulmonary MTB infection have a 71-fold higher chance of being RT-PCR-based test positive compared with patients without the infection. This ratio suggests a potential role for RT-PCR assay in confirming (ruling in) an MTB infection in paediatrics.

The summary estimates of sensitivity, however, were 56 (95\% CI 51-62) and 87 (95\% CI 82-91) for pulmonary and extra-pulmonary samples, respectively, higher in extra-pulmonary than pulmonary TB possibly due to quality and paucity of tubercle bacilli in paediatrics sputum samples. Sensitivity estimates were more variable than specificity. According to the AUC and the DOR (see Table 2), diagnostic accuracy of RT-PCR based assay was excellent for the extra-pulmonary specimens over pulmonary and these results are acceptable for clinical practice (see Table 2).

A RT-PCR based assay for the detection of MTB has a high sensitivity and specificity. The PLR and NLR showed that RT-PCR may serve as a suitable method when confirming or excluding TB. It was anticipated that there would be some degree of heterogeneity of diagnostic measures across studies due to differences in sample size, RT-PCR based assay type, reference test of mycobacterial culture (either liquid or solid or both) and TB prevalence. 
Table 3 Subgroup analyses by impact of RT-PCR based assays on lower- and middle-income countries (LMICs) versus upper middleincome countries (UMICS). We will assess sources of data to these graders

\begin{tabular}{|c|c|c|c|c|}
\hline Test property & $\begin{array}{l}\text { Summary of measure test accuracy }{ }^{a} \\
(95 \%)\end{array}$ & Test of heterogeneity & & \\
\hline $\begin{array}{l}\text { Lower-MICs } \\
\left(n=8 ;{ }^{b} 2047\right) \\
\text { AUC }=0.99\end{array}$ & & $\begin{array}{l}x 2 \\
(\text { d.f. }=7)\end{array}$ & P & $p$ value \\
\hline Sensitivity & $65(58-72)$ & 44.28 & 84.20 & $<0.001$ \\
\hline Specificity & $99(99-99$ & 10.46 & 33.10 & 0.1639 \\
\hline Positive likelihood ratio (PLR) & $86.61(46.72-160.53)$ & 5.97 & 0.0 & 0.5432 \\
\hline Negative likelihood ratio (NLR) & $0.3670 .233-0.578$ & 29.54 & 76.30 & $<0.001$ \\
\hline Diagnostic odd ratio (DOR) & $311.43(106.76-908.51)$ & 11.25 & 37.8 & 0.1280 \\
\hline $\begin{array}{l}\text { Upper-MICs } \\
\left(n=12{ }^{b} 3487\right) \\
\text { AUC }=0.99\end{array}$ & & 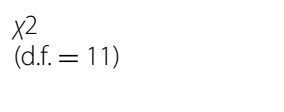 & R & $p$ value \\
\hline Sensitivity & $68(63-73)$ & 197.71 & 94.40 & $<0.001$ \\
\hline Specificity & $97(96-98)$ & 291.40 & 96.20 & $<0.001$ \\
\hline Positive likelihood ratio (PLR) & $80.90(10.31-634.9)$ & 247.81 & 95.6 & $<0.001$ \\
\hline Negative likelihood ratio (NLR) & $0.20(0.09-0.42)$ & 228.53 & 95.2 & $<0.001$ \\
\hline Diagnostic odd ratio (DOR) & $522.72(107.04-2552.8)$ & 50.80 & 78.30 & $<0.001$ \\
\hline
\end{tabular}

${ }^{\mathrm{a}}$ Random effects model, $\chi 2$ chi-squared, d.f. degree of freedom, $l^{2} 1$-squared, ${ }^{b}$ number of specimens, $n$ number of studies, $C l$ confidence interval, $A U C$ area under receiver operating characteristics curve, $P T B$ pulmonary tuberculosis, EPTB extra-pulmonary tuberculosis

High heterogeneity was found among studies (as defined by the $\chi^{2}$ and $I^{2}$ statistics) for all measures. Subgroup analyses were therefore performed pre-specified to investigate potential sources of the observed between-study heterogeneity. It was assumed that the disparity was likely a result of the differences in the type of index test (RTPCR assay) or target sequence gene of MTB used or the income categories of countries in the included studies.

In the current study, a limited number of subgroup analyses were conducted by comparing the impact of RT-PCR based assays on categories of lower- and middleincome countries (LMICs) versus upper middle-income countries (UMICs) to reduce the degree of study heterogeneity. Heterogeneity assessed by $\chi^{2}$ and $I^{2}$ statistics between these subgroups was generally not very strong (seeTable 3). However, significant heterogeneity of diagnostic accuracy measures was expected and was, indeed, found among studies and the random-effects model partially accounted for the between-study heterogeneity.

Some degree of heterogeneity of diagnostic measures across studies was found due to differences in sample size, sample type, study design, target genes and clinical settings of the participants. Thus, it is possible that when evaluating RT-PCR assays using a more sensitive index test can lead to overestimation of the assay's sensitivity.

\section{Strengths and weaknesses of the review}

An important strength of this study was its comprehensive search strategy using several search engines to identify any unpublished studies in the form of conference abstracts or proceedings. Screening, study selection, quality assessment and data extraction were undertaken independently and reproducibly by two reviewers, as such human error should be limited. The problem of missing data was reduced by contacting the authors of the publications. In accordance with the study guidelines, potential publication bias and heterogeneity was explored $[69,70]$. Random-effects analysis and subgroup analyses in anticipation of heterogeneity were used. Evaluation of level of publication bias was not formally carried out in the study; however, the risk of this bias was reduced by not restricting the search to any language. Another strength of this review is that RT-PCR based assay has comparably high sensitivity with paucibacillary specimens (EPTB) and high throughput capacities particularly in paediatrics where getting quality sputum samples is difficult.

This review does, however, have some limitations in assessing issues such as cost-effectiveness and the net effect of RT-PCR assay on clinical care and patient outcomes. Also, because of poor reporting, an analysis of the effect of factors such as laboratory infrastructure was not possible. Secondly, empirical evidence suggests that studies with significant or favourable results are more likely to be published than those with non-significant or unfavourable results [71]. In addition, literature search strategies are inherently imperfect, and studies can be missed, it is therefore possible that a proportion of such studies with non-significant or unfavourable results may have been missed. Other limitations are conflicts of interest of 
study authors particularly from industry supported studies and fully keeping up to date with the primary studies in this rapidly evolving field. Two of the included studies in our analysis were case-control, and thus subject to potential bias that could have affected outcomes.

Given that RT-PCR based assays in this review cover a range of different target genes and procedures, it is not possible to recommend any one over another owing to a lack of direct test comparisons. Our findings should be interpreted in the context of the quality of studies and reporting and variability in study quality. Diagnostic studies in general [72] and TB diagnostic studies in particular $[73,74]$ seem to be beset by these problems.

The use of guidelines such as the Standards for Reporting of Diagnostic Accuracy (STARD) might improve the quality of reporting of primary studies [75]. Future studies should compare commercialised RT-PCR assays to determine their diagnostic accuracy. Further work is required to devise a simple and cost-effective RT-PCR test for an efficient diagnosis of PaeTB that can be used routinely in resource-poor countries.

\section{Conclusion}

According to this review and meta-analysis, RT-PCR assay has a high sensitivity and specificity for EPTB with turn-a-round time of $2 \mathrm{~h}$ compared with reference culture-based assay that takes between 2 and 10 weeks for detection. Supporting the fact that where quality pulmonary (sputum) samples could not be collected in paediatrics, the use of extra-pulmonary samples should be considered. Overall, RT-PCR based assay accuracy was superior for extra-pulmonary samples (sensitivity 87 (95\% CI 82-91); specificity 100 (95\% CI 99-100) as opposed to pulmonary samples sensitivity $56(95 \%$ CI 51-62); specificity 97 (95\% CI 96-98). The specificity was high for both pulmonary and extra-pulmonary samples indicating that the test should be adopted as the first-line test for ruling in TB infection but may need to be an add-on test to rule out the disease. It offers an alternative robust approach to detect MTB in paucibacillary PaeTB samples, showing rapid results with good diagnostic accuracy. The results of our study should provide encouragement to health-care providers for treating children with TB. Nevertheless, the results of this assay should be interpreted in parallel with clinical findings and the results of conventional tests, but the assay may contribute significantly for an early diagnosis and exert an impact on the clinical management and control of TB. The findings do not support the use of this assay for excluding a diagnosis of TB on its own as a standalone test. It offers an incremental benefit as an add-on test to other investigations. RT-PCR assays, combining amplification and detection in a single run, seem to offer advantages over conventional assays including the mycobacterial culture-based reference standard which is slow.

It is anticipated that our findings will aid healthcare practitioners and policymakers in adopting the use of this assay on a routine basis. Most importantly, this can be as a point-of-care-test which will help in the global control of PaeTB, particularly in developing countries with a high burden of the disease.

\section{Supplementary Information}

The online version contains supplementary material available at https://doi. org/10.1186/s13643-021-01836-w.

Additional file 1. PRISMA checklist.

Additional file 2. Search strategy.

Additional file 3. Quality assessment of diagnostic accuracy studies-2 tool.

Additional file 4. Figures of Subgroup analyses (LMICs).

Additional file 5. Figures of Sub-group analyses (UMICS).

Additional file 6. Definition of statistical parameters.

\section{Acknowledgements}

We would like to thank Derick Yates of the library at Birmingham Women's and Children's Hospital NHS Foundation Trust for his support especially during development of the search strategy for this systematic review protocol.

\section{Authors' contributions}

EB formulated the research question and designed the study. EB developed the search strategy. $E B$ and $B C$ drafted the manuscript. EB, BC, BO and GM critically reviewed the manuscript for content. EB reviewed the statistical analysis. All authors have read and approved the final version of the manuscript.

\section{Authors' information}

EB is a Senior Lecturer/Clinical Placement Tutor and Programme Leader in Applied Biomedical Science of School of Pharmacy and Biomolecular Sciences, Liverpool John Moores University.

$\mathrm{BC}$ is a Consultant Microbiologist, Royal London Hospital, Barts Health NHS Trust, London UK.

BO is a Research Laboratory Manager, HIV/GUM Research Laboratory, Chelsea \& Westminster Hospital, 369 Fulham Road, London, Greater London, SW10 $9 \mathrm{NH}, \mathrm{UK}$.

GM is a Specialist Biomedical Scientist Microbiology Department, IPP Pathology First, Dobson House, Bentalls, Basildon, SS14 3BY, UK.

\section{Funding}

None

\section{Availability of data and materials}

The datasets used and/or analysed during the current study are available from the corresponding author on reasonable request.

\section{Declarations}

Ethics approval and consent to participate

Not applicable

Consent for publication

Not applicable

\section{Competing interests}

The authors declare that they have no competing interests. 
Received: 13 January 2021 Accepted: 12 October 2021

Published online: 27 October 2021

\section{References}

1. Zar HJ, Workman LJ, Little F, Nicol MP. Diagnosis of pulmonary tuberculosis in children: assessment of the 2012 National Institutes of Health Expert Consensus Criteria. Clin Infect Dis. 2015;61:S173-8.

2. Pai M, Behr M, Dowdy D, et al. Tuberculosis. Nat Rev Dis Primers. 2016;2:16076.

3. Global tuberculosis report 2020. Geneva: World Health Organization; 2020. Licence: CC BY-NC-SA 3.0 IGO.

4. Debulpaep S, Corbière V, Levy J, Schelstraete $P$, et al. Contribution of QuantiFERON-TB gold-in-tube to the diagnosis of mycobacterium tuberculosis infection in young children in a low TB prevalence country. Pediatr. 2019. https://doi.org/10.3389/fped.2019.00291.

5. Togun TO, MacLean E, Kampmann B, Pai M. Biomarkers for diagnosis of childhood tuberculosis: A systematic review. PLoS One. 2018;13:e0204029. https://doi.org/10.1371/journal.pone.0204029.

6. Cowger TL, Wortham JM, Burton DC. Epidemiology of tuberculosis among children and adolescents in the USA, 2007-17: an analysis of national surveillance data. Lancet Public Health. 2019:4:e506.

7. World Health Organization. Global tuberculosis report 2020 tuberculosis/ global-tuberculosis-report-2020/factsheet.pdf. Accessed: 15 Dec. 2020]

8. Peter $\mathrm{JH}$, Zelalem T, Ritu B. Tuberculosis in children. Pediatr Rev. 2019;40:168-78.

9. WHO consolidated guidelines on tuberculosis. Module 3: diagnosis rapid diagnostics for tuberculosis detection, 2021 update. Geneva: World Health Organization; 2021. Licence: CC BY-NC-SA 3.0 IGO

10. Carvalho ACC, et al. Epidemiological aspects, clinical manifestations, and prevention of pediatric tuberculosis from the perspective of the End TB Strategy. J Brasileiro De Pneumologia. 2018;44:134-44. https://doi.org/10. 1590/s1806-37562017000000461.

11. Lamb GS, Starke JR. Tuberculosis in infants and children. Microbiol Spectrum. 2017:5:TNMI7-0037-2016.

12. Welday SH, Kimang'a AN, Kabera BM, Mburu JW, Mwachari C, et al. Stool as appropriate sample for the diagnosis of mycobacterium tuberculosis by Gene Xpert test. Open J Res Dis. 2014;4:83-89. http://dx.doi.org/10. 4236/ojrd.2014.43012

13. Bonnave PE, Raoult D, Drancourt M. Gastric aspiration is not necessary for the diagnosis of pulmonary tuberculosis. Eur J Clin Microbiol Infect Dis. 2013:32:569-71.

14. Walters E, Demers AM, van der Zalm MM, et al. Stool Culture for Diagnosis of Pulmonary Tuberculosis in Children. J Clin Microbiol. 2017;55(12):3355-65.

15. Getahun H, Matteelli A, Chaisson RE, Raviglione M. Latent Mycobacterium tuberculosis infection. N Engl J Med. 2015;372(22):2127-35.

16. Snow KJ, Sismanidis C, Denholm J, et al. The incidence of tuberculosis among adolescents and young adults: a global estimate. Eur Respir J. 2018;51:1702352

17. Houben RM, Dodd PJ. The global burden of latent tuberculosis infection: a re-estimation using mathematical modelling. PLoS Med. 2016;13(10):e1002152.

18. Dodd PJ, Gardiner E, Coghlan R, Seddon JA. Burden of childhood tuberculosis in 22 high-burden countries: a mathematical modelling study. Lancet Glob Health. 2014;2(8):e453-9.

19. Mtabho CM, et al. Childhood tuberculosis in the Kilimanjaro region: lessons from and for the TB programme. Trop Med Int Health. 2010;15:496-501.

20. Gröschel MI, van den Boom M, Migliori GB, et al. Prioritising children and adolescents in the tuberculosis response of the WHO European Region. Eur Respir Rev. 2019;28:180106.

21. Tiwari S, Mehta P, Nataraj G, Kanade S. Diagnosis of pediatric pulmonary tuberculosis with special reference to polymerase chain reaction based nucleic acid amplification test. Int J Mycobacteriol. 2015;4:48-53.

22. Hepple P, Ford R, McNerney R. Microscopy compared to culture for the diagnosis of tuberculosis in induced sputum samples: a systematic review. Int J Tuberc Lung Dis. 2012:16(5):579-88.

23. WHO. Xpert MTB/RIF assay for the diagnosis of pulmonary and extrapulmonary TB in adults and children: WHO policy update. Geneva: WHO; 2016.
24. Moussa HS, Bayoumi FS, Mohamed AMA. Gene Xpert for direct detection of mycobacterium tuberculosis in stool specimens from children with presumptive pulmonary tuberculosis. Ann Clin Lab Sci. 2016;46:198-203.

25. Andriyoko B, Janiar $H$, Kusumadewi $R$, et al. Simple stool processing method for the diagnosis of pulmonary tuberculosis using GeneXpert MTB/RIF. Eur Respir J. 2019;53:1801832.

26. Rahman SMM, Maliha UT, Ahmed S, Kabir S, Khatun R, Shah JA, et al. Evaluation of Xpert MTB/RIF assay for detection of Mycobacterium tuberculosis in stool samples of adults with pulmonary tuberculosis. PLoS One. 2018;13(9):e0203063.

27. Kobayashi M, Ray SM, Hanfelt J, Wang YF. Diagnosis of tuberculosis by using a nucleic acid amplification test in an urban population with high HIV prevalence in the United States. PLoS One. 2014;9(10):e107552.

28. European Centre for Disease Prevention and Control. World Health Organization Regional Office Europe. Tuberculosis surveillance in Europe 2009. Stockholm: European Centre for Disease Prevention and Control; 2011

29. Macíasa A, Sánchez-Montalváa A, Salvadora F, Villarc A, et al. Epidemiology and diagnosis of pleural tuberculosis in a low incidence country with high rate of immigrant population: A retrospective study. Int J Infect Dis. 2019;78:34-8.

30. White S, Schultz T, Enuameh YAK. Synthesizing evidence of diagnostic accuracy. Philadelphia: Lippincott Williams \& Wilkins; 2011.

31. Nathavitharana RR, Jijon DF, Pal P, Rane S. Diagnosing active tuberculosis in primary care. Br Med J. 2021;374:n1590.

32. Moher D, Liberati A, Tetzlaff J, Altman DG. The PRISMA Group Preferred reporting items for systematic reviews and meta-analyses: the PRISMA statement. PLoS Med. 2009;6(7):e1000097.

33. Whiting PF, Rutjes AW, Westwood ME, Mallett S, Deeks JJ, Reitsma JB, et al. QUADAS-2: a revised tool for the quality assessment of diagnostic accuracy studies. Ann Intern Med. 2011;155:529-36.

34. Dickersin K. Publication bias: recognizing the problem, understanding its origins and scope, and preventing harm. In: Rothstein HR, Sutton AJ, Borenstein $M$, editors. Publication bias in meta-analysis: prevention, assessment and adjustments. Chichester: Wiley; 2005. p. 11-33.

35. Deville WL, Buntinx F, Bouter LM, Montori VM, de Vet HC, van der Windt DA, et al. Conducting systematic reviews of diagnostic studies: didactic guidelines. BMC Med Res Methodol. 2002;2:9-12. https://doi.org/10. 1186/1471-2288-2-9.

36. Bates M, O'Grady J, Maeurer M, Tembo J, Chilukutu L, Chabala C, et al. Assessment of the Xpert MTB/RIF assay for diagnosis of tuberculosis with gastric lavage aspirates in children in sub-Saharan Africa: a prospective descriptive study. Lancet Infect Dis. 2013;13(1):36-42. https://doi.org/10. 1016/S1473-3099(12)70245-1. Epub 2012;(5). PMID: 23134697.

37. Chipinduro M, Mateveke K, Makamure B, Ferrand RA, Gomo E. Stool Xpert ${ }^{\circledR}$ MTB/RIF test for the diagnosis of childhood pulmonary tuberculosis at primary clinics in Zimbabwe. Int J Tuberculosis Lung Dis. 2017;21(2):161-6.

38. Gous N, Scott LE, Khan S, Reubenson G, Coovadia A, Stevens W. Diagnosing childhood pulmonary tuberculosis using a single sputum specimen on Xpert MTB/RIF at point of care. S Afr Med J. 2015;105(12):1044-8. https://doi.org/10.7196/SAMJ.2015.v105i12.8585.

39. El Khéchine A, Henry M, Raoult D, Drancourt M. Detection of Mycobacterium tuberculosis complex organisms in the stools of patients with pulmonary tuberculosis. Microbiology (Reading). 2009;155(7):2384-9 DOI: 1510.1099/mic.0.026484-0.

40. LaCourse SM, Chester FM, Preidis G, McCrary LM, Arscott-Mills T, Maliwichi $M$, et al. Use of Xpert for the diagnosis of pulmonary tuberculosis in severely malnourished hospitalized Malawian children. Pediatr Infect Dis J. 2014;33(11):1200-2.

41. Memon SS, Sinha S, Sharma SK, Kabra SK, Lodha R. Diagnostic Accuracy of Xpert Mtb/Rif Assay in Stool Samples in Intrathoracic Childhood Tuberculosis. J Tuberc Ther. 2018;3(2):115.

42. Mesman AW, Soto M, Coit J, et al. Detection of Mycobacterium tuberculosis in pediatric stool samples using TruTip technology. BMC Infect Dis. 2019;19(563):7.

43. Nhu NTQ, Ha DTM, Anh ND, et al. Evaluation of Xpert MTB/RIF and MODS assay for the diagnosis of pediatric tuberculosis. BMC Infect Dis. 2013;13:31.

44. Nicol MP, Spiers K, Workman L, Isaacs W, Munro J, Black F, et al. Xpert MTB/ RIF testing of stool samples for the diagnosis of pulmonary tuberculosis in children. Clin Infect Dis. 2013:57(3):e18-21. 
45. Nicol MP, Workman L, Isaacs W, Munro J, Black F, Eley B, et al. Accuracy of the Xpert MTB/RIF test for the diagnosis of pulmonary tuberculosis in children admitted to hospital in Cape Town, South Africa: a descriptive study. Lancet Infect Dis. 2011;11(11):819-24.

46. Nicol MP, Workman L, Prins M, Bateman L, Ghebrekristos Y, Mbhele S, et al. Accuracy of Xpert Mtb/Rif Ultra for the Diagnosis of Pulmonary Tuberculosis in Children. Pediatr Infect Dis J. 2018;37(10):e261-3.

47. Oberhelman RA, Soto-Castellares G, Gilman RH, Caviedes L, Castillo ME, Kolevic $L$, et al. Diagnostic approaches for paediatric tuberculosis by use of different specimen types, culture methods, and PCR: a prospective case-control study. Lancet Infect Dis. 2010;10(9):612-20.

48. Yin Q-Q, Jiao WW, Han R, Jiao AX, Sun L, Tian JL, et al. Rapid diagnosis of childhood pulmonary tuberculosis by Xpert MTB/RIF assay using bronchoalveolar lavage fluid. Biomed Res Int. 2014;2014:6. https://doi.org/10. 1155/2014/310194.

49. Rachow A, Clowes P, Saathoff E, Mtafya B, Michael E, Ntinginya EN, et al. Increased and expedited case detection by Xpert MTB/RIF assay in childhood tuberculosis: a prospective cohort study. Clin Infect Dis. 2012;54(10):1388-96.

50. Sekadde MP, Wobudeya E, Joloba ML, Ssengooba W, Kisembo H, BakeeraKitaka S, et al. Evaluation of the Xpert MTB/RIF test for the diagnosis of childhood pulmonary tuberculosis in Uganda: a cross-sectional diagnostic study. BMC Infect Dis. 2013;13(133). https://doi.org/10.1186/ 1471-2334-13-133.

51. Walters E, van der Zalm MM, Palmer M, Bosch C, Demers AM, Draper H, et al. Xpert MTB/RIF on stool is useful for the rapid diagnosis of tuberculosis in young children with severe pulmonary disease. Pediatr Infect Dis J. 2017;36(9):837-43.

52. Wang X, Wu YH, Zhang K, Guan C, Gao X, Wang M. Value of real-time polymerase chain reaction in bronchoalveolar lavage fluid for diagnosis of pediatric pulmonary tuberculosis. Braz J Infect Dis. 2013;17(6):718-9.

53. Wolf H, Mendez M, Gilman RH, Sheen P, Soto G, Velarde AK, et al. Diagnosis of pediatric pulmonary tuberculosis by stool PCR. Am J Trop Med Hyg. 2008;79:893-8.

54. Zar HJ, Workman L, Isaacs W, Munro J, Black F, Eley B, et al. Rapid molecular diagnosis of pulmonary tuberculosis in children using nasopharyngeal specimens. Clin Infect Dis. 2012;55(8):1088-95.

55. Zar HJ, Workman L, Isaacs W, Dheda K, Zemanay W, Nicol MP. Rapid diagnosis of pulmonary tuberculosis in African children in a primary care setting by use of Xpert MTB/RIF on respiratory specimens: a prospective study. Lancet Glob Health. 2013;1(2):e97-e104.

56. Hartzes AM, Morgan CJ. Meta-analysis for diagnostic tests. J NuCl Cardiol. 2019;26:68-71.

57. Umemneku Chikere CM, Wilson K, Graziadio S, Vale L, Allen AJ. Diagnostic test evaluation methodology: a systematic review of methods employed to evaluate diagnostic tests in the absence of gold standard - An update. PLoS One. 2019;14(10):e0223832.

58. Zamora J, Abraira V, Muriel A, Khan K, Coomarasamy A. Meta-DiSc: a software for meta-analysis of test accuracy data. BMC Med Res Methodol. 2006;6:31-42. https://doi.org/10.1186/1471-2288-6-31.

59. Salanti G, Nikolakopoulou A, Sutton AJ, et al. Planning a future randomized clinical trial based on a network of relevant past trials. Trials. 2018;19:365.
60. Leeflang MM, Deeks JJ, Takwoingi Y, Macaskill P. Cochrane diagnostic test accuracy reviews. Syst Rev. 2013;2:82-7. https://doi.org/10.1186/ 2046-4053-2-82.

61. Gagnier JJ, Moher D, Boon H, et al. Investigating clinical heterogeneity in systematic reviews: a methodologic review of guidance in the literature. BMC Med Res Methodol. 2012;12:111.

62. Higgins JPT, Thomas J, Chandler J, Cumpston M, Li T, Page MJ, Welch VA (eds). Cochrane Handbook for Systematic Reviews of Interventions version 6.2. Cochrane. 2021. Available from www.training.cochrane.org/ handbook.

63. Causse M, Ruiz P, Gutiérrez Aroca JB, Casal M. Comparison of two molecular methods for rapid diagnosis of extrapulmonary tuberculosis. J Clin Microbiol. 2011:49:3065-7. https://doi.org/10.1128/JCM.00491-11.

64. Lange C, Mori T. Advances in the diagnosis of tuberculosis. Respirology. 2010;15:220-40.

65. Mulalo M, Julitha M. The use of real-time polymerase chain reaction and an adenosine deaminase assay for diagnosing pleural tuberculosis. Afr J Lab Med. 2019;8(1):1-5.

66. Kik SV, Schumacher S, Cirillo DM, et al. An evaluation framework for new tests that predict progression from tuberculosis infection to clinical disease. Eur Respir J. 2018;52:1800946.

67. Nice_guideline_on_tb_treatment_and_prevention_2016.pdf. https:// www.nice.org.uk/guidance/ng33. Accessed 24 Sept 2021.

68. Seith S, Yadav R, Mewara A, Dhatwalia SK, Sharma M, Gupta D. Evaluation of in-house mpt64 real-time PCR for rapid detection of Mycobacterium tuberculosis in pulmonary and extrapulmonary specimens. Braz J Infect Dis. 2012;16:493-4.

69. Chopra KK, Singh S. Newer diagnostic tests for tuberculosis, their utility, and their limitations. Curr Med Res Pract. 2020;10:8-11.

70. Christopher DJ, Schumacher SG, Michael JS, Luo R, Balamugesh T, Duraikannan $\mathrm{P}$, et al. Performance of Xpert MTB/RIF on pleural tissue for the diagnosis of pleural tuberculosis. Eur Respir J. 2013;42:1427-9.

71. Martindale JL, Wakai A, Collins SP, et al. Diagnosing acute heart failure in the emergency department: a systematic review and meta-analysis. Acad Emerg Med. 2016;23(3):223-42.

72. Ayorinde AA, Williams I, Mannion R, et al. Publication and related biases in health services research: a systematic review of empirical evidence. BMC Med Res Methodol. 2020;20:137.

73. Cohen JF, Korevaar DA, Altman DG, et al. STARD 2015 guidelines for reporting diagnostic accuracy studies: explanation and elaboration. BMJ Open. 2016;6:e012799.

74. Small PM, Perkins MD. More rigour needed in trials of new diagnostic agents for tuberculosis. Lancet. 2000;356:1048-9.

75. Bossuyt PM, Reitsma JB, Bruns DE, Gatsonis CA, Glasziou PP, Irwig L, et al. STARD 2015: an updated list of essential items for reporting diagnostic accuracy studies. BMJ. 2015:351:h5527.

\section{Publisher's Note}

Springer Nature remains neutral with regard to jurisdictional claims in published maps and institutional affiliations.

Ready to submit your research? Choose BMC and benefit from

- fast, convenient online submission

- thorough peer review by experienced researchers in your field

- rapid publication on acceptance

- support for research data, including large and complex data types

- gold Open Access which fosters wider collaboration and increased citations

- maximum visibility for your research: over $100 \mathrm{M}$ website views per year

At BMC, research is always in progress.

Learn more biomedcentral.com/submissions 